\title{
Promoting adolescent EFL students' decision-making through work plans gathered in their portfolios
}

\author{
Promoción de la toma de decisiones en adolescentes \\ estudiantes de inglés como lengua extranjera mediante \\ planes de trabajo recopilados en sus portafolios
}

\author{
Yudiht Milena Martin Celis ${ }^{1}$ \\ Melba Libia Cárdenas ${ }^{2}$
}

\section{Abstract}

This article gives account of the results of an action research project that focused on how students develop decision-making processes in the creation of collaborative work plans by using their portfolios in English classes. The study was carried out in a Colombian public school located in a deprived area, and involved eighth grade students with low English competence. Data were collected through students' portfolios, interviews, field notes, and surveys. The results suggest that students can develop their autonomy if they are involved in collaborative decision-making practices and if awareness-raising processes take place.

Key words

Collaborative work, portfolios, students' decision-making, work plans.

Resumen

En este artículo se reportan los resultados de un proyecto de investigación acción que se centró en cómo los estudiantes desarrollan procesos de toma de decisiones en la creación de planes de trabajo colaborativos, mediante el uso de sus portafolios en la clase de inglés. El estudio se realizó en un colegio público colombiano, ubicado en una zona deprimida, y en él participaron estudiantes de octavo grado con baja competencia en lengua inglesa. En la recolección de datos se emplearon portafolios de los estudiantes, entrevistas, notas de campo y encuestas. Los resultados sugieren que los estudiantes pueden desarrollar un perfil autónomo, si se les involucra en prácticas colaborativas que propicien la toma de decisiones y si llevan a cabo procesos de concientización.

\section{Palabras clave}

Trabajo colaborativo, portafolios, toma de decisiones de los estudiantes, planes de trabajo.

Artículo recibido el 9 de septiembre de 2013 y aprobado el 7 de febrero de 2014

1 Universidad Pedagógica Nacional, Instituto Técnico Central de la Salle, and Secretaría de Educación Distrital de Bogotá. yudithmar@hotmail.com

2 Universidad Nacional de Colombia, Bogotá, Colombia. mlcardenasb@unal.edu.co. PhD Candidate in the area of education (Universidad de Zaragoza, Spain - Fundación Carolina Scholarship). 
Universidad Pedagógica Nacional

Facultad de Humanidades

In our daily pedagogical duties teachers and students need to undertake learning and teaching processes as a reciprocal practice. Such a process implies different views and actions so that students and teachers can promote their independence. Because of this, it was decided to explore new ways of having students work in class by using learning strategies and work plans which can foster students' active participation in their lessons and, in the end, lead to autonomy. It was thought that changes in teaching and learning practices could give students more opportunities to interact with their classmates and to be more conscious of and responsible for their learning experience.

In Colombia, the idea of promoting autonomy in English language teaching was first presented by the COFE (Colombian Framework for English) Project - a binational enterprise that engaged 27 Colombian universities, the Ministry of Education and the British Council in strengthening the preparation of English teachers. It highlighted the importance of autonomy in English language learning as well as in teacher education (Aparicio, Benavides, Cárdenas, Ochoa, Ospina, and Zuluaga, 1995) and further prompted teachers' involvement in studying, implementing and investigating it in the country. To cite just some of them, there have been studies dealing with foreign language learning in higher education (Lagos \& Ruiz, 2007), promoting autonomy through self-assessment and learning strategies (Sierra \& Frodden, 2003; Fandiño, 2007), teachers' and students' autonomy (Ariza, 2008; Pineda \& Frodden, 2008; Usma \& Orrego, 2009), and power relations (Rico, 2003; Ramos Holguín, 2009). However, not much has been published in connection to the implementation of those aspects in Colombian public high schools.

This research project was an attempt to promote student-centered learning practices in the English classes at CEID Porfirio Barba Jacob public school, located in an underprivileged area, in Bogotá, Colombia. Such new practices involved the creation of work plans in students' portfolios in order for them to develop decision-making abilities. In the following sections we present the research problem, the theoretical framework, the method and the pedagogical intervention that served as the framework for the study. Next, we present the findings and the conclusions. Finally, we gather some implications for the different parties that might have a bearing on sustained language policies and practices leading to students' empowerment as autonomous individuals.

\section{Research Problem}

Following educational policies, the CEID Porfirio Barba Jacob School has tried to give its students the opportunity to learn the English language so they can reach an intermediate level to communicate in different areas. Emphasis has been given to reading and writing in order to ensure students success in the national exam (called ICFES Exam, Saber 11). However, some limitations have made this process difficult and unsuccessful. At the institutional level we have class size, with 45 or 50 students in each class, multilevel classes, limited pedagogical resources, lack of connection between students' learning at school and what they can apply in their lives, and social problems found in the community (poverty, drugs, and insecurity). As far as students' deficiencies we should mention lack of students' motivation, students' low level of autonomy, misconceptions about grades and processes in the learning experience, and low performances in English.

Twelve training sessions on "learning to learn" were conducted. They included setting objectives and learning strategy implementation in order to promote students' decision-making skills in regular classes. Then, a Saturday course was organized for those interested in participating in the current project. Hence, some students took part in the pedagogical intervention described below, and which focused on work plans and portfolios. Within this framework, a research project was set up in order to explore options for giving students opportunities for learning involvement and thus, redirect their attitude towards the foreign language. The following research questions were posed: 
Main question:

What do students' portfolios show about the development of decision-making processes in the creation of collaborative work plans in the English class?

Related questions:

1. How is students' autonomy evidenced in their decision-making work plans gathered in their portfolios?

2. What kind of strategies do students use to create and monitor their own work plans in the learning process in EFL?

3. What role do students play in the development of decision-making work plans in the learning process in EFL?

\section{Theoretical Framework}

Four main topics guided the development of the study. They are autonomy, the use of classroom decision-making practices, portfolios, and work plans.

\section{Autonomy}

Autonomy has been viewed and studied from different perspectives and the literature is extensive. Holec (1981) considers it as a method and a goal. He defines autonomy as the ability one has to control his/her own learning. He introduces two conditions for becoming an autonomous learner. The first one has to do with the context in which autonomy is being developed and the second one is related to the abilities and competences for the student to be responsible for his/her learning. He also asserts that these two conditions let students themselves develop gradually from a dependent stage to an independent one. Following this idea, Dickinson (1987) defines autonomy as a situation in which the learner is totally responsible for all decisions concerned with his/her learning and the implementation of those decisions. He also identifies three elements that contribute to the development of autonomy in language learning: self-management, self-monitoring and self-assessment. On the other hand, Benson (2001) points out a difference between autonomy and selfinstruction or self-study, and defines autonomy as the ability to take control of one's own learning and not as a method of self-education.

In order to foster autonomy among learners, Dam, Eriksson, Little and Miliander (1990) pinpoint two requirements: active student participation in classroom learning and a meaningful learning environment in which students can interpret new information and incorporate it to what they already know. Additionally, they portray an autonomous learner as "a person who knows how to learn and can use this knowledge in any learning situation she/he may encounter at any stage in his /her life" (Dam et al., 1990, p.56). Likewise, Gardner and Miller (1996) assert that autonomous learners are "those who initiate the planning and the implementation of their own learning program" (p. 23).

Other publications have added to our understanding of autonomy. Fenner and Newby (2000) point out that "autonomy in foreign language learning is more an 'attitude' or even a philosophy than a methodology. It is not concerned with one specific method, but allows for any method which the individual learner finds beneficial to his learning purposes" (p. 56). More recently, Zembylas and Lamb (2008) interrogate the notion of autonomy in education and assert that "being an autonomous learner does not necessarily mean being in control. But it certainly implies that the learner's critical consciousness should occupy a social and political space that interrogates any taken-for-granted assumptions about autonomy" (p. 33). This critical/postmodern view acknowledges the learner's agency and claims that through self-constitution the student governs his/her own self. In turn, teaching is "about inspiring students to become vigilant and suspicious of claims made by one's own self as well as by others about being 'free' and 'autonomous'" (Zembylas \& Lamb, 2008, p. 32).

Considering the views presented so far, it was thought that the implementation of work plans in students' portfolios could let students begin to plan their learning objectives. This way, we could 
Universidad Pedagógica Nacional

Facultad de Humanidades

promote decision-making processes in their own learning. In this respect, some classroom practices such as raising awareness, planning objectives, implementing learning strategies and using alternative assessment can allow students to develop their autonomy and promote learners' real involvement in their learning experience.

Raising awareness is considered as a starting point to develop an autonomous learning course (Scharle \& Szabo, 2000). If students are conscious of what they are doing in their classes, of their learning styles and of the importance of choosing the best options to learn, they can begin an autonomous journey. For this to happen, new activities need to be introduced to change attitudes and redefine roles in class. Needless to say, this process moves smoothly and requires the learners' conscious participation. Supporting this view, Sanmartí, Jorba and Ibañez (2002) assert that promoting self-reflection allows students to recognize their weaknesses and strengths in the learning process and in doing so they can create their own "action model." In turn, this explicit training can encourage a collaborative spirit between the teachers and learners and promote the use of learning strategies in order to develop learners' autonomy. In relation to this, Breen and Littlejohn (2000) assert that this new students' and teachers' role change implies new classroom interactional patterns and syllabus negotiation.

Learning awareness and planning objectives are main constructs in the autonomy development route. Hence, the teacher can lead students through a pre-designed syllabus which includes specific students' objectives. In connection with this idea, Breen and Littlejohn (2000) assert that "teachers have to mediate between the requirements of the syllabus and the different learning agendas of students in the class" (p.8). These learning agendas are what we call "work plans." They are shaped by the students' prior knowledge and learning experience and their learning objectives in language learning. The authors add that these work plans 'comprise the learners' own learning priorities, their changing learning needs, their different preferred strategies and styles of learning, the different value and functions they give to the language classroom and the people in it, and so on" (p. 9). In addition to this use, students' work plans also involve students' self-evaluation and their own specific learning objectives, taking into account the class syllabus. In doing so, students "get their own interpretations of what is done in the classroom and how it relates to their own learning agendas" (p. 9).

Besides raising awareness, the development of autonomous learning entails the use of learning strategies in the classroom. Oxford (1990) considers them as practical techniques to make learning time more effective and asserts that self-directed learners need to identify the strategies that make them more effective language learners. These strategies will vary according to their goals and objectives. For the purpose of this research project we understand a language strategy as a useful tool to improve conscious understanding and learning of the target language.

The conceptions depicted above triggered us to explore how students take control of their own learning, and how they handle their own learning strategies through the use of their work plans. We further explore what is meant by other autonomous practices such as decision-making and the use of portfolios. How they are introduced, and their implications in the creation of work plans are also considered.

\section{Decision-Making Processes in School}

When students, teachers and parents are involved in negotiation practices, a sense of responsibility is developed, the relations between teachers and learners are closer and the teaching-learning experience is meaningful and pertinent for the actors involved in it. Decision-making practices enable individuals to develop participation skills as citizens in democratic processes.

According to Breen and Littlejohn (2000) there are some principles which underlie the use of negotiation in the language classroom:

- Negotiation is a means for responsible membership of the classroom community. 
- Negotiation can construct and reflect learning as an emancipatory process.

- Negotiation can activate the social and cultural resources of the classroom group.

- Negotiation enables learners to exercise their active agency in learning.

- Negotiation can enrich classroom discourse as a resource for language learning.

- Negotiation can inform and extend teachers' pedagogic strategies.

Breen and Littlejohn (2000) also suggest that if teachers and students want to carry out a decisionmaking practice, they have to negotiate in four main areas such as:

- The purpose of their work together (purposes)

- The content or subject matter of their work (content)

- Their various ways of working together (methodology)

- Their preferred means of evaluation of the efficiency and quality of the work and its outcomes so that new directions in the work can be identified (evaluation).

The principles behind the use of negotiation and the areas to negotiate can be seen as advantages for students to take a more active role. With these premises in mind, students can be engaged in decision-making activities leading to the creation of work plans for their learning process. Referring to negotiation, Breen and Littlejohn (2000) underline that "participation may shift appropriately from the whole group, to small group and individual work. Additionally, assessment of achievements or evaluation of the whole process may come at the end" (p. 31). They describe the negotiation cycle as a pyramid, which depicts levels of application of the negotiation cycle (see Figure 1).
Figure 1. The Curriculum Pyramid: Levels of Focus for the Negotiation Cycle (Based on Breen \& Littlejohn, 2000, p. 35)

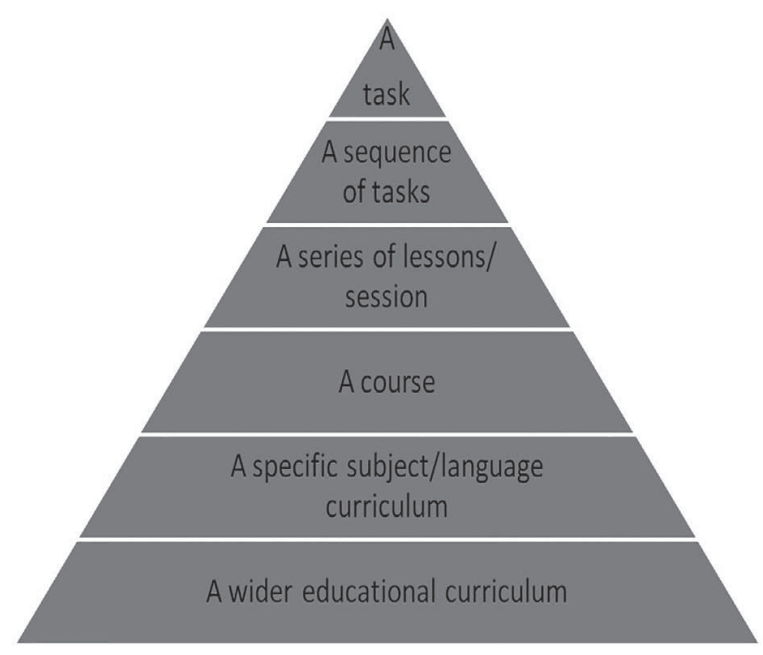

The authors state that changes produced by implemented negotiation practices can be seen at different levels and can enrich the daily pedagogical practice from the "task"- the smallest unit on which the cycle focuses and which can be seen as the most immediate location of learning work - up to a "wider educational curriculum". The broadest levels of attention for the negotiation cycle are a specific subject/language curriculum or an educational curriculum, at either institutional or state level. Keeping those ideas in mind, for the purpose of this project, we implemented decision-making activities, such as suggesting homework activities and setting objectives in students' work plans through a series of lessons or sessions - see the third level of Figure1.

In the development of those activities, we took into consideration what is meant by personal, interactive and procedural negotiation (Breen \& Littlejohn, 2000). Personal negotiation has to do with the psychological process in individuals because "it engages such mental capacities as discriminating, analyzing and synthesizing, memorizing or recalling" (p. 6). Likewise, interactive negotiation is considered as a process that has a psycholinguistic purpose in that it is seen as "a facilitative means for generating comprehensible input" (p. 7). Lastly, procedural negotiation has to do with process and context decisions such as "who will 
Universidad Pedagógica Nacional

Facultad de Humanidades

work with whom, in what ways, with what resources and for how long, upon what subject matter or problem, and for what purposes " (p. 8). In addition, the authors remark that alongside the negotiation processes that can take place in the classroom, the students can set out particular criteria for success, write evaluative reports identifying their strengths and weaknesses, and create portfolios of their work, among others. In the following paragraphs we describe some theoretical assumptions and studies about the use of portfolios in English classes.

\section{Portfolios}

Portfolios have been used in our context for the purpose of archiving students' records and to evidence success in learning processes. Genesee and Upshur (1996) describe portfolios as "a purposeful collection of students' work that demonstrates to students and others their efforts, progress and achievements in given areas" (p. 99). The authors assert that this kind of work could include students' participation involving decision making practices when they select contents, ways of evaluation and self-assessment.

Regarding types of portfolios, Bailey (1998) divides them into two categories: progress portfolio and achievement portfolio. The former shows improvement over students' courses. The latter is a collection of their best works over their past courses. These portfolios are divided into four main parts: an introductory section which is an overview of the contents, an academic works section which demonstrates the students' improvement in their process, a personal section which includes the students' journals, and finally an assessment section with students' evaluations from their peers and themselves. This final part contains a record of the reflection process, which includes critical thinking in the assessment procedure of the language learning experience.

A different categorization was proposed by Omalley and Valdez (1996): showcase portfolios, collection portfolios and assessment portfolios. Showcase portfolios are used to display a student's best work to parents and school administrators.
Collection portfolios include a student's work that shows how a student deals with daily class assignments; and assessment portfolios are focused on reflections of specific learning goals that contain a systematic collection of student work, student assessment and teacher assessment. Bearing in mind this last type of portfolio, Bailey (1998) explains that "portfolios are accumulative in nature and demand a great deal of input and responsibility from the language learner, as well as a tremendous time commitment from teachers" (p. 219). Regarding this study, we opted for a combination of collection and assessment portfolios (Omalley \& Valdez, 1996) because it gathers students' work and their reflections about their learning process. Hence, we encouraged them to include in their portfolios samples of their work (writing samples, audio or video-tapes and reports or products), self-assessment (mainly reflections) and criteria for evaluation.

Students need to know how their work will be evaluated and by what standards their work will be judged. In connection to this, Omalley and Valdez (1996) claim that we should specify criteria and standards and provide representative samples of what these look like. This way, we can help students set goals and work toward attaining them. In order to develop those criteria, teachers and students need time to discuss criteria and promote engagement in goal setting. A good example of this kind of assessment in a portfolio could be rubrics creation as a key element of lesson or course planning.

There is agreement as to the advantages of using portfolios. Schafer (as cited in Bailey, 1998) asserts that "in looking over an ESOL [English to Speakers of Other Languages] portfolio, a student, parents, or teachers will not only see the student light of her/ his language development, but also in terms of his/ her cultural background, personality, special abilities and talents or perhaps limitations, too" (p. 217). The use of portfolios in class encourages students to reflect on their work, to analyze their progress, and to set improvement goals (implementing decisionmaking classroom practices). Another important advantage of portfolios relates to its assessment 
approach. According to Omalley and Valdez (1996), in assessment portfolios students and teachers become partners who deliberate over portfolio contents and their interpretation. What matters in this dialogue is not who has the last word, but how they can reach consensus. Thus, we need to devote time, gain experience and be open to playing new roles.

\section{Method}

This study was guided by the principles of action research with the purpose of facing the challenge of implementing a pedagogical course of action that allows us to engage in and document change and improvement, describe and interpret a social reality - in this specific case, the English learning process in a public school in a deprived area. According to Cohen, Manion and Morrison (2000), action research is defined as "a small-scale intervention in the functioning of the real world and a close examination of the effects of such an intervention" (p. 227). Burns (2010) also explains that action research involves taking a self-reflective, critical, and systematic approach to exploring our own teaching contexts.

In this specific case, the students and the English teacher were involved as reflective participants in their own personal and professional growth, and joined efforts to develop the level of awareness of the quality of their achievements. Following this last idea, action research may empower individuals and social groups to take control over their lives within a framework of promotion rather than the suppression of generalizable interests (Habermas, as cited in Cohen et al., 2000, p. 227).

According to Burns (1999), action research involves the following steps: analyze the state of the art, identify and reflect upon the possible weaknesses found in it; next, problematize a situation, choose a solution, plan and analyze, and reflect on data collection in order to get findings. Accordingly, we analysed the English curriculum, and then a needs analysis was conducted. As a result, the following aspects were identified: some weaknesses such as students' motivation, heterogeneous groups, students' low level of autonomy (teachers/friends' dependence), misconceptions about grades and processes in the learning experience, students' low performance in English, social community problems, and a lack of connection between their learning at school and what they could apply in their lives. Subsequently, the research concern was posed; data were collected and analysed following triangulation processes. The analysis of data fostered reflection and improvement in daily pedagogical practice.

\section{Context of the Study}

This project was implemented with eighth graders at CEID Porfirio Barba Jacob, a public school located in the seventh zone of Bogotá (Colombia) which is one of the poorest and most violent areas of the city. Its pedagogical institutional project ( $\mathrm{PEI}=$ Proyecto Educativo Institucional) is based on technical education oriented towards commerce and business management. According to this, English classes emphasize reading and writing skills without disregarding listening and speaking development. By using project work, the school wants to educate students so that they become capable of working in the business field, supporting their community and developing their own life projects.

These students have a lot of problems related to malnutrition, drugs, alcohol, dysfunctional family structures, displacement, poverty and premature pregnancies, among others. In addition, for three years the school went through difficult times that included the restoration of buildings. This, together with many unexpected activities, often affected the normal development of the classes. Additionally, students' responsibility and commitment with their academic and social duties had decreased enormously. For these reasons, it was decided to look for new ways to promote students' independent work and to explore ways in which the school community could participate in decision-making processes for learning English. 
Universidad Pedagógica Nacional

Facultad de Humanidades

\section{Participants}

The population of this study was composed of 22 eighth grade students. Their ages ranged between 12 and 15 years of age. This group was selected based on previous teaching observation and its own characteristics about their learning experience. All of the students chosen got the lowest marks in eighth grade and during the first semester of the year they failed English. The participants also shared some of the following characteristics: students' dependence on teachers, poor academic performance and lack of parental support. However, students still were highly motivated to learn English and liked facing new challenges.

The research team was composed of the English teacher and her research supervisor. The former was a participant observer and the latter, a non-participant observer. This distribution of roles allowed us to validate data as explained below.

\section{Data Collection Instruments and Procedures}

Four collection instruments were used: students' portfolios, field notes, semi-structured interviews, and surveys. After having chosen a group of students and making sure the members really wanted to participate in the research project - as was expressed by their approval, commitment and their parents' consent -, their English classes were observed and field notes were recorded by the English teacher. Students' portfolios were also collected to find out the strategies they used to create and monitor their own work plans in their learning process. Some surveys were included in the portfolios. They provided information about the learning process too. Finally, the English teacher interviewed some students in order to inquire about their role in the development of their decision-making work plans.

The data were collected once a week during twelve English classes of four-hoursessions on Saturdays. These sessions were arranged with the participants due to problems with the school schedule, which was affected by the reconstruction of the building. In addition, the Saturday course was seen as an alternative to provide additional spaces for students to study the language.

Data analysis was done following grounded theory (Strauss \& Corbin, 1990; Freeman, 1998), which allowed us to identify patterns and categories. Open coding procedures were applied to analyze the data gathered. As Strauss and Corbin (1990) propose, "generalizations, concepts, or hypotheses emerged from an examination of data -data grounded in the context itself" (p. 61). This allowed us to discover new relationships, concepts, and understanding, rather than verification of predetermined hypotheses. The process of coding was applied to categorize the data, taking into account constant comparisons of similarities and differences from the information gathered. For the purpose of trustworthiness, triangulation was done by using several instruments and by considering information provided by different participants (Lincoln \& Guba, 1985).

\section{Pedagogical Design}

The pedagogical intervention that framed this study consisted of five stages (see Figure 2). In the first stage, a first pedagogical unit was developed; then students' portfolios were created. Next, the teacher shared the information about the English program and learning strategies with the whole group and asked them to keep some reflections in a file or portfolio. We focused on course aims (What is expected?), program description (How is it going to be developed?) and learning strategies (How can I do it?).

A pedagogical unit is understood as an educational work proposal which combines the students' needs and the curriculum requirements in a didactic way. It is based on a specific educational philosophy, curricular model, language approach and learning vision. Each pedagogical unit included the students' own work plans, a learning-to-learn training part and a section on language learning formation. This last part was connected to other subjects and included work on listening, writing, grammar and vocabulary. At the end of the unit, students had to 
work on individual and cooperative projects reinforcing what they had learnt in the pedagogical unit.

Figure 2. Pedagogical Intervention Phases

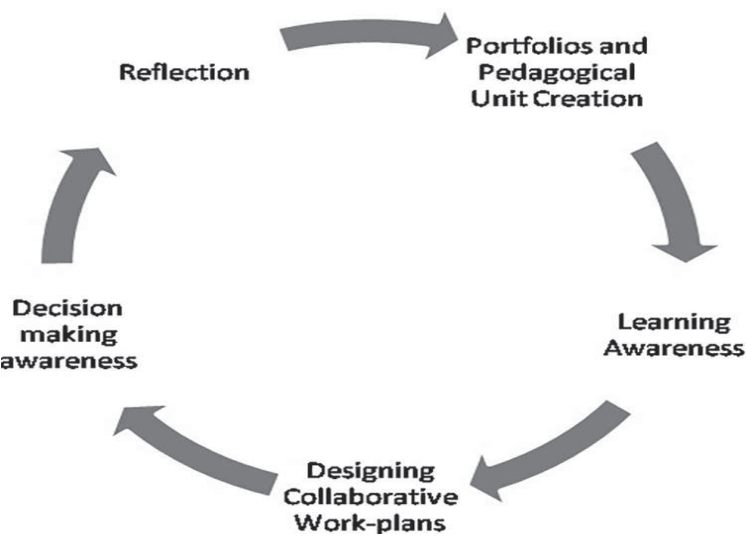

In the second stage, learning awareness and students' common learning practices were explored. This was done through materials for learning strategies training, a description of the English program and learning surveys. Then, in the decision making awareness stage a sample of a work plan was discussed with the students in order to create their own work plan for each English session.

At the beginning of the class, students were asked to compare, using the class program, what they have learnt and what was missing in order to choose what they were going to study that day. This step was done in order to make them aware of what they had learnt and how it had been learnt. After choosing the topic from the class program, they wrote their expectations and a possible plan to learn what they had chosen from the class program. Later, students did the unit's exercises and proposed some homework activities. At the end students asked questions; they were answered by the teacher in the following session. The work plans were divided into six parts (see Figure 3).
Figure 3. Students' Work Plan Sample

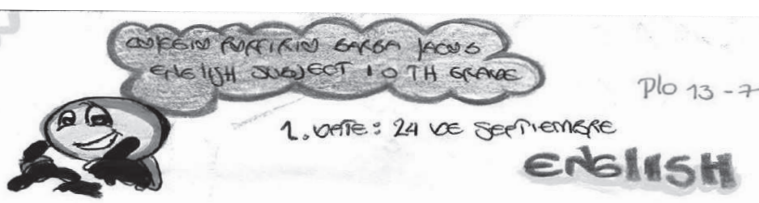

1. Plan for todoy (objectives, time, strategies, action.)=

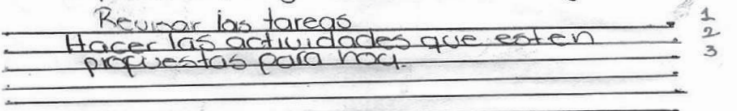

2 Class notes (what is new

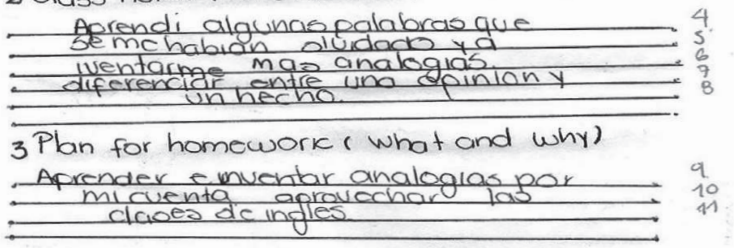

4 final Doubts.

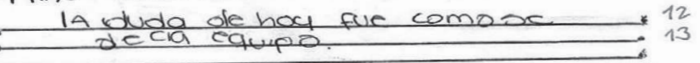

Finally, it should be noted that time restrictions and the school's unplanned activities affected the continuity of the pedagogical intervention. The first phases took more time than expected and the process was very slow. For this reason, we applied just one research cycle. Nonetheless, and as can be read in the following section, it provided interesting insights that can guide us and other teachers in further implementations.

\section{Findings}

The analysis of data let us identify three main categories (see Table 1). The first category refers to ways in which students' autonomy was evidenced through the use of work plans in their portfolios and embraces how students reflect upon and systematize their experiences in order to go further in their learning. The second category deals with a categorization of the students' strategies used to create and monitor their work plans. The third category has to do with the students' possible roles and their kind of involvement in the development of decision-making work plans. In the subsequent sections these three categories and their subcategories are described further. Samples are included in 
Universidad Pedagógica Nacional

Facultad de Humanidades

the language they were originally written in, and participants and sources identified with codes as follows: S 1 (Survey 1); St 1 (Student 1); Int L 2-6 (Interview, lines 2-6); T (Teacher); FN (Field notes).

Table 1. Categories Found in the Data

\begin{tabular}{|c|c|}
\hline Categories & Sub-categories \\
\hline $\begin{array}{c}\text { Taking control of one's own } \\
\text { learning }\end{array}$ & $\begin{array}{c}\text { Systematizing and reflecting } \\
\text { upon experiences }\end{array}$ \\
\hline $\begin{array}{c}\text { Applying learning strategies } \\
\text { Meta-cognitive strategies } \\
\text { Affective strategies } \\
\text { Social strategies }\end{array}$ \\
\hline Changing roles to fulfill goals & Follower and viewer \\
\hline
\end{tabular}

\section{Taking Control of One's Own Learning}

This category refers to students' practices carried out when they created their work plans in English class. The most common practice involved in such a process was students' planning of their own learning, particularly in issues having to do with the clarity of what they have learnt and how the learning process was organized. Within this learning planning, a subcategory emerged. It has to do with the systematization of the information and reflection upon experience, that is to say, the learning planning practice, as evidenced in the following students' comments:

Me parecieron buenos (los planes de trabajo) porque uno planea, es como si organizara para hacer un trabajo y al organizarse es más fácil aprender. (S 2, L 7-8)

No me fue difícil plantear los objetivos de clase ... No, porque eso es lo más fácil que uno puede plantear porque eso es lo que uno piensa hacer durante este curso y como yo ya los tenia planteados para mí no fue tan difícil. (Int 8, L 5-7)
These comments show how students planned, organized and reflected upon what they did in class in order to further their learning. According to what was found, these practices promote students' autonomy, decision making and language learning in the class. Supporting this aspect, Gardner and Miller (1996) state that autonomous learners are "those who initiate the planning and the implementation of their own learning program" (p. vii). Reflecting upon it, Nunan (1995) also states that setting and planning objectives can promote decision making practices in the classroom.

Additionally, the use of portfolios showed that they were a means for students to write and reflect upon their learning experiences. According to this, Omalley and Valdez (1996) explain that the use of portfolios in class encourages students to reflect on their work, to analyze their progress and to set improvement goals, as expressed by one student:

Pues eran... con las ideas que uno ponía. Entonces uno ya sabía lo que iba a ver, con las tareas uno ya uno tenía más imaginación y pues los planes ... uno escribía y uno ya se acordaba bien. (Int 3, L 15-17)

In the portfolios, two main issues were evidenced: The first one has to do with how the development of work plans promoted a sense of planning and organizing learning. The second issue refers to how these work plans allowed them to organize what they were learning and review what they were systematizing as a strategy of self-monitoring and class involvement. To this end, Breen and Littlejohn (2000) state that students using portfolios can get their own interpretations of what is done in the classroom and how it relates to their own learning agendas. Accordingly, one participant responded:

Eso [sugerir] ayudó porque yo creo que ... de acuerdo a las sugerencias se fueron mejorando las clases. Digamos ... estas eran más didácticas por la escucha y todo eso ... porque ya era más amplio el tema, no sólo se quedaba en lo que íbamos a ver sino que ampliábamos todos con nuestras opiniones. (Int 9, L 30-33) 
This comment evidences that work plans also promote critical thinking because students can express their thoughts and what they are doing in the process from a critical point of view (Torres Díaz, 2009). This author emphasizes the idea of using portfolios as a way to make public students' opinions and feelings during their learning process. In this sense, the implementation of work plans in the portfolios can raise students' awareness, and it is considered as the starting point to develop students' autonomy (Scharle and Szabo, 2000).

The data collected showed that self-reflection can support or stimulate students' awareness. Following this idea of promoting self-reflection through the use of portfolios, we worked on raising students' consciousness about their responsibility and autonomy, introduced new roles in class, and fostered conscious participation, cooperation and use of learning strategies.

According to Sanmartí et al. (2002), promoting self-reflection in the classroom develops students' responsibility. This self-reflection allows students to recognize their weaknesses and strengths in the process, and when they are doing so they can create their own "action model". Some students expressed:

En ellos [los planes de trabajo] podemos escribir lo que aprendimos y las dudas que teníamos. Además de que podíamos escribir actividades para mejorar en los aspectos trabajados. (S4, L 8-10)

Pues la importancia de eso ... pues saber qué era lo que nosotros hacíamos todos los sábados y también lo que en cada clase ... lo que íbamos aprendiendo para así saber qué era lo que nos habían enseñado. (Int 2, L 23-25)

También los planes de clase ayudaron harto porque eso uno los veía y ya sabía lo que uno que iba a trabajar. Entonces de acuerdo a lo que uno veía, pues, planteaba los objetivos y después complementaba. (Int 9, L 9-11)

These comments evidenced a methodological awareness in which students reflected upon what they were doing and how they were doing it. In con- nection to this methodological awareness, Sanmartí et al. (2002) state that the responsibility of self-regulation must be on the students' own shoulders. They must recognize their own learning characteristics and adopt their own "logic" or methodology and strategies for self-monitoring this logic.

Likewise, and referring to portfolios, Genesee and Upshur (1996) underline the benefits of using them in class as an integral part of the instructional planning. They state some learning advantages such as students' involvement, responsibility for their learning, interaction with others (classmates and teachers), students' ownership, and students' ability to think critically about schoolwork. Another advantage of the use of portfolios is the individualized monitoring of learning by the teacher. In our particular case, students felt that the teacher's attention was more focused on them than in daily weekday classes. In addition to that, feedback was usually perceived by students. These practices also evidence the interactive and active aspects of using portfolios in class.

\section{Applying Learning Strategies}

We bore in mind the importance of adopting the right strategies to make learning time more effective and contribute to more effective learning processes (Oxford, 1990). Interestingly, it was observed that the explicit training in "learning to learn" promoted the use of some tips which helped students in their language learning. Next, we can find some evidences taken from students' interviews:

De pronto ya uno sabía que ... digamos... la escucha, habla. Entonces pues uno miraba como por ese tema ... a buscar qué de pronto me ayudaba ahí. (Int 10, L 23-26)

Me pareció importante porque ... sí ... tal vez le va mejor a uno tal vez escuchando a otros; mejor escribiendo y otros aprenden más si solo leen y así. (Int 11, L 26-28) 
Universidad Pedagógica Nacional

Facultad de Humanidades

In these statements we can note how useful the metacognitive strategies were. Furthermore, we can observe their connection to the students' learning styles (visual, analytic or auditory), their goals (what they wanted to learn in this class) and the kind of language ability (their English competence level) that they were working on.

Three different learning strategies were used by the students for monitoring their own work plans. According to Oxford (1990), learning strategies are divided into metacognitive, affective and social strategies. Regarding the meta-cognitive strategies, we found that students relied on arranging their plans, setting goals and objectives, overviewing already known material and self-evaluation. Also, we could observe that students used affective strategies to lower anxiety and encourage themselves. As far as social strategies are concerned, they used learning with others. Now, we examine how these strategies were evidenced in the data analysis.

According to Oxford (1990), meta-cognitive strategies involve centering learning and this can be carried out by over-viewing and linking new material with already known material. Some of the students' autonomous characteristics are the systematic review of their work plans, the reflection on what has already been learnt, the evaluation of effects, and the development and use of self-evaluative criteria (Luna Cortés \& Sánchez Lujan, 2005). A testimony to illustrate this reads as follows:

Pues sí porque con eso [work plans] ... miraba y de ahí sacaba. O sea, miraba lo que yo había hecho en esas clases y entonces de ahí uno más o menos sabe qué es lo que tiene que escribir y poner en las hojas. (Int 2, L 27-29)

Era más fácil para estudiar. Uno revisaba el plan de clase y miraba lo que uno había puesto que aprendió de nuevo y entonces, de acuerdo a eso a uno se le hacía más fácil acordarse de lo que había visto. (Int 9, L 23-25)

On the other hand, some students underline the importance of some factors that can help their learning such as the number of students per class, normal practices and expectations, among others. Supporting the importance of the learning environment, Ariza (2008) asserts that "the implementation of autonomous work requires a proper atmosphere where students and teachers feel comfortable and supported when engaging in a new teaching-learning paradigm" (p. 69). In this project, the number of students in class, the schedule and activities represented an innovation for them. Students expressed that they felt more satisfied and motivated with their learning and this course's characteristics:

Porque es como ... más calmado ... más relajado ... Como que a uno le explican mejor (...) porque había poquitos niños y uno ya pone cuidado bien a las clases y no es tanta bulla ni nada. (Int 12, L .26-30)

Sí, he aprendido mucho y como los sábados son más relajados, uno se siente sin presión. (S2, L13-14)

Pues uno no pierde el tiempo y en vez de estar vagando, aprende algo ... Y pues para reforzar mi inglés ... claro. (Int 10, L 61-62)

Setting their own objectives to practice in class was considered as a core action in the implementation of this project because it had to do with promoting decision-making abilities in the students. Ariza (2008) asserts that setting clear objectives and having achievable purposes can introduce students' reflection and decision making in the classes. In turn, these practices promote autonomy because students are taking responsibility for their learning process (Dickinson, 1987; Ariza, 2008). That is why self-awareness was a key factor in the implementation of this project. Hence, it was mandatory that students knew and were aware of what they were going to learn each session and why the proposed activities could help them to reach their objectives.

The use of learning with others as a social strategy was also evidenced because students had to interact to reconstruct meaning (Oxford, 1990). This interaction took place mainly with their peers, but their family (parents at home) and the teacher 
were also involved in the process. At the beginning students did not feel comfortable working in groups because the groups were first assigned by the teacher, but then students were able to overcome their differences and consider their partner as a good teacher (role change), a useful and helpful development for their learning. It was another type of student-teacher interaction in the class. Hence, the usual power relation between the teacher and the students was moved towards a cooperative and supportive alliance in the classroom. Accordingly, Breen and Littlejohn (2000) say that encouraging collaborative spirit between teachers and learners can promote the use of learning strategies and develop students' autonomy.

Pues al comienzo no entendía, pero después como ya como a las tres clases Germán (un compañero) me explicó y ahí ya empecé a entender. (Int 3, L 8-9)

No, pues los cuatro, las mesas [los estudiantes trabajaban en grupo]. Estuvo bien porque si a uno le faltaba él le ayudaba o algo así y pues nos compartíamos las ideas todos. (Int 10, L 56-57)

Porque si uno no entiende uno se ayuda con las personas o les (...) les va ayudando, y eso pues me parece chévere. (Int 12, L 35-36)

Pues en la casa le preguntaba a mi papá y mi papa me decía: 'busque un diccionario y lo traduce'. Cuando no encontraba algunas palabras me decía: 'prenda el computador y lo traduce ahí. Y lo traducía y me dijo: 'primero contéstelo en inglés y déjelo aparte para que así vaya aprendiendo más. (Int 6, L 17-20)

This last comment shows how learning English could take place outside of the classroom -although learning English was still associated with translating. Concerning family homework support at home we could witness how parents suggested methodological strategies to their children in order to overcome difficulties and how they could guide their children at home, suggesting strategies concerning their homework. In this case the parents' role was active in the students' learning.

\section{Changing Roles to Fulfill Goals}

This category has to do with the different roles students could adopt through the process of creating and monitoring work plans. Bearing in mind the context, we favored "procedural negotiation" which, as already explained, deals with taking decisions about "who will work with whom, what subject matter and what activities were suitable for this problem" (Breen \& Littlejohn, 2000, p. 8). During this process, two main students' roles were visible. The first one was characterized by a passive role, that of "follower and viewer", and it was mainly observed in the first stages of the creation of work plans. The second one was an active role called "explorer and collaborator", showed at the end of the project. Next, we characterize these two students' roles or profiles.

The first profile "follower and viewer" is closely related to authority-oriented students (Ariza, 2008, p. 59). Our participants showed a huge need for teacher's support and approval. They did what the teacher said and preferred others, such as the teacher or classmates, to take the decisions for them. A couple of examples are the following, to wit:

Porque vine casi todos los sábados ... hice todo lo que me ponían. (S 14, L2-3)

Me pareció fácil porque los pude resolver todos completos, como lo había dicho la profesora. (Int 6, L 6-8)

They (students) usually stand up and asked teacher if they were doing it (the class exercise) well.

(FN 3, L 26-27)

At the beginning, these "followers and viewers" repeatedly asked about what they had to do, but not about strategies or paths they could explore for learning more about a topic. They were just interested in showing that they were working and that they deserved a good grade. It was a feeling like studying for others, learning for others (teachers, parents), not learning for themselves. Sometimes 
Universidad Pedagógica Nacional

Facultad de Humanidades

students expressed that they had run out of ideas and expressed that their writing difficulties were their main limitation to actively participate or to engage in the creation of work-plans.

Tuve dificultad un poco con el plan de trabajo porque hay veces no sé qué escribir. (S9, L 11-12)

Me pareció a veces difícil porque a veces uno no sabe qué tarea ponerse y se le vienen las mismas ideas de siempre. (S 10, L 13-15)

When I reviewed this exercise, I realized that many students did not write anything in their work plans.

(FN 4, L 25-29)

Fortunately, when students were trained in learning to learn and started setting their own objectives, their profile started to change from a passive one to an active involvement. At the same time the teacher's role was also different: a guide, a mediator who had to facilitate the resources and knowledge, but with the students themselves having to decide how to do it and what to do in their learning. In this respect, Breen and Littlejohn (2000) assert that "students can get [their] own interpretations of what is done in the classroom and how it relates to their work plans" (p. 9). One student expressed:

Me pareció bueno porque ahí uno podía decir qué era lo que faltaba en las clases. (Int 7, L 22)

The second profile, "explorer and collaborator", was more evident at the end of the project. It was characterized by the students' initiative, creativity, organization and revision of products. They also showed their willingness to go further and to selfevaluate what they were doing. Moreover, students liked working in groups and making decisions about their learning process. They organized what they learnt in their work plans, set their own learning objectives and could create a cooperative learning relation with their classmates. This way they showed independent behavior and an autonomous profile.

Ese punto es como para que uno mismo ponga la tarea y tenga ideas para aprender más rápido.
Entonces eso ayuda mucho para...para uno desenvolverse en la tarea para hacerla más fácil. (Int 3, L 38-40)

Eso [sugerir] ayudo porque yo creo que ... de acuerdo a las sugerencias se fueron mejorando las clases ... Y estas (clases) eran más didácticas ... porque ya era más amplio el tema, no sólo se quedaba en lo que íbamos a ver sino que ampliábamos todos con nuestras opiniones. (Int 9, L 30-33)

Pues los cuatro [estudiantes], las mesas ... estuvo bien porque si a uno le faltaba él le ayudaba o algo así y pues nos compartíamos las ideas todos. (Int 10, L 56-57)

In summary, it could be seen how decisionmaking practices, fostered in the English class, let students reflect and review what they were doing and go further in their learning. In addition to this, it could be observed how students feel when their opinions or suggestions are taken into account in the class organization and lesson planning. Reinforcing this view as a final goal, these decision-making practices can enable students to develop participation as citizens in democratic processes. In our particular case, if we start promoting students' active involvement in the planning of learning processes, deciding and evaluating what they are doing - we will be promoting autonomous profiles for future citizens who can self-monitor all aspects of their lives, as proposed in the school PEI.

\section{Conclusions}

This investigation sought to examine what students' portfolios show about the development of decisionmaking processes in the creation of collaborative work plans in English classes. Adolescents, and especially those who live in underprivileged contexts like the ones of our participants, need plenty of opportunities to develop proficiency in the English language. In this area, as well as in any field of the curriculum, we cannot forget that "learning is a matter of repertoire: starting with a recognition of the life world experience and using this experience 
as a basis for extending what one knows and what one can do" (Kalantzis \& Cope, 2000, p. 124). Data suggested that portfolios are unique opportunities for students to learn to monitor their own progress and encourage them to take responsibility for meeting goals set jointly with the teacher and, hopefully, with parents' support. Next, we highlight the findings in response to the three subquestions we posed in our study.

How is students' autonomy evidenced in students' decision-making work plans gathered in their portfolios? We explored how students take control of their learning and concluded that they usually plan and regulate their process using two main practices. The first one deals with how they systematize and organize what they are learning in their work plans. In turn, the second practice embraces students' selfreflection and how it lets them go further in their English learning experience. This "systematized" experience involves how students organize what they did and learnt, and how they reviewed and used it in a real context.

When the students systematized what they learnt, they were able to retain, monitor and evaluate their learning using these work plans in their portfolios as tools to remember, to consult, to organize and to explore what they were learning. Doing this, students could adapt their own class methodology to their needs, interests and capabilities.

What kind of strategies do students use to create and monitor their own work plans in the learning progress in EFL? We found that the most common strategies used are meta-cognitive strategies, affective strategies and social strategies. In relation to meta-cognitive strategies, students arrange and plan their learning using the following steps: finding out about language learning, organizing, setting objectives, and identifying the purpose of language tasks. Likewise, lowering anxiety and encouraging themselves were considered as key practices in order to promote affective strategies. In addition, students were aware of their language improvement because of two main factors: the positive environment in the class, without teacher's or classmates' pressure, and their motivation level, which was evident when they noticed progress in their English learning.

Another strategy used was learning with others and this aspect includes the support of students' classmates, their family and the teacher. When students faced different tasks in class, they worked cooperatively and asked their classmates or the teacher for explanations, or shared what they had understood about a specific topic. At home, some students took advantage of their family support and used it as a strategy to clarify doubts or just to go further in their learning.

What role do students play in the creation of decision-making work plans? Two main profiles appeared during the whole pedagogical implementation. At the beginning of the course the role of "follower and viewer" was the most common profile, but through time, this role changed towards an "explorer and collaborator" profile. Whereas the follower and viewer role shows a teacher-dependent relationship and demands external supervision, the explorer and collaborator is more in tune with the individual's decision to adopt a more autonomous route and to make informed decisions.

\section{Implications}

Though results proved positive, some further reflections and implications also emerged. They embrace roles played by the government, schools, teachers, parents and students. In the first place, policies proposed by the government have to ensure that enough resources, better spaces and supportive personnel are available at school in order to generate suitable learning environments in which autonomous learning can be applied. The second issue concerns how the school practices help the development of autonomy. For this to happen, the school must create negotiation spaces in which students, parents and teachers can take decisions regarding the learning process. Thirdly, in autonomy development a new teachers' role is vital. We need to develop some characteristics such as being more open minded, making decisions and being aware of our roles as advisors, reflective professionals, tolerant practitioners, 
Universidad Pedagógica Nacional

Facultad de Humanidades

explorers, negotiators and listeners. In that sense, universities have to think about future teachers' profiles and make sure that teacher educators can also receive updates in new teaching models and more learning centered approaches.

The fourth implication has to do with parents' involvement in their children's learning. Parents' support outside the class is a key point to empower students' autonomy in their lives. This support has to push students to move from a dependent state towards a more self-directed one. Finally, students have to reflect more upon what they are doing and take more responsibility for what they are learning and how they are learning it. To do this, they should be encouraged and guided to take challenges and explore further what they really want to do in their lives.

\section{References}

Aparicio, B., Benavides, J., Cárdenas, M. L., Ochoa, J., Ospina, C. M., \& Zuluaga H., O. (1995). Learning to teach and teaching to learn - Working Document 5. London, UK: Thames Valley University.

Ariza, J. (2008). Unveiling students' understanding of Autonomy: Puzzling out a path to learning beyond the EFL classroom. PROFILE Issues in Teachers' Professional Development, 10(1), 47-73.

Bailey, K. M. (1998). Learning about language assessment: Dilemmas, decisions, and directions. Boston, MA: Heinle \& Heinle.

Benson, P. (2001). Teaching and researching autonomy in language learning. Harlow, UK: Pearson Education.

Breen, M., \& Littlejohn, A. (2000). Classroom decisionmaking. Negotiation and process syllabuses in practice. Cambridge, UK: Cambridge University Press.

Burns, A. (1999). Collaborative action research for English language teachers. Cambridge, UK: Cambridge University Press.

Burns, A. (2010). Doing action research in English language teaching: A guide for practitioners. New York, NY: Routledge.

Cohen, L., Manion, L., \& Morrison, K. (2000). Research methods in education ( $5^{\text {th }}$ ed.). New York, NY: Routledge Falmer.
Dam, L., Eriksson, R., Little, D., \& Miliander, J. (1990). Towards a definition of Autonomy. In T. Trebbi (Ed.). Third Nordic workshop on developing autonomous learning in the FL classroom. Bergen, NO: University of Bergen. Retrieved from http://www.warwick. ac.uk/go/dahla/archive/trebbi_1990

Dickinson, L (1987). Self-instruction in language learning. Cambridge, UK: Cambridge University Press.

Fandiño, Y. J. (2007). The explicit teaching of socioaffective language learning strategies to beginner EFL students at the Centro Colombo Americano: An action research study (Master's thesis). Bogotá, CO: Universidad de La Salle.

Fenner, A.B., \& Newby, D. (2000). Learner autonomy in approaches to materials designed in European textbooks: Implementing principles of authenticity: Learner autonomy and cultural awareness. Strasbourg, FR: Council of Europe Publishing.

Freeman, D. (1998). Doing teacher research: From inquiry to understanding. Boston, MA: Heinle and Heinle Publishers.

Gardner, D., \& Miller, L. (1996). Task for independent language learning. Alexandria, VA: Teachers of English of Other Languages.

Genesee, F., \& Upshur, J. (1996). Classroom based evaluation in second language education. Cambridge, UK: Cambridge University Press.

Holec, H. (1981). Autonomy is the ability to take charge of one's own learning. Oxford, UK: Pergamon.

Kalantzis, M., \& Cope, B. (2000). Changing the role of schools. In B. Cope \& M. Kalantzis (Eds.). Multiliteracies: Literacy Learning and the design of social futures (pp. 121-148). South Yarra, AU: Macmillan.

Lagos, J., \& Ruiz, Y. (2007). La autonomía en el aprendizaje y en la enseñanza de lenguas extranjeras: Una mirada desde el contexto de la educación superior [Autonomy in the learning and teaching of foreign languages: A view from the higher education context]. Matices en Lenguas Extranjeras, 1. Retrieved from http://www.revistamatices.unal.edu.co/

Lincoln, Y. S., \& Guba, E. G. (1985). Naturalistic inquiry. Beverly Hills, CA: Sage.

Luna Cortés, M. L., \& Sánchez Lujan, D. K. (2005). Profiles of autonomy in the field of foreign languages. PROFILE Issues in Teachers' Professional Development, 6, 133-140. 
Nunan, D. (1995). Collaborative language learning and teaching. Cambridge, UK: Cambridge University Press.

Omalley, J. M., \& Valdez, L. (1996). Authentic assessment for English language learners. Practical approaches for learners. New York, NY: Addison-Wesley Longman.

Oxford, R. (1990). Language learning strategies: What every teacher should know. New York, NY: Newbury House.

Pineda, D., \& Frodden, C. (2008). The Development of a Novice Teacher's Autonomy in the Context of EFL in Colombia. PROFILE Issues in Teachers' Professional Development, 9(1), 143-162.

Ramos Holguín, B. (2009). Power relations through oral interaction: A dichotomy between traditional and autonomous English classrooms. In M. L. Cárdenas (Ed.). Investigación en el aula en L1 y L2. Estudios, experiencias y reflexiones [Research in the $\mathrm{L} 1$ and $\mathrm{L} 2$ classroom. Studies, experiences and reflections] (pp. 109-129). Bogotá, CO: Centro Editorial Facultad de Ciencias Humanas.

Rico, C. (2003). Empoderamiento e institución educativa [Empowerment and the educational institution]. Interlenguajes, 3(2), 55-84.

Sanmartí, N., Jorba, J., \& Ibañez, V. (2002). Aprender a regular y a autorregularse [Learning to regulate and to self-regulate]. In J. I. Pozo \& C. Monereo (Eds.). El aprendizaje estratégico [Strategic learning] (pp. 301-322). Madrid, ES: Santillana.

Scharle , A., \& Szabo, A. (2000). Learner autonomy. A guide to develop learner responsibility. Cambridge, UK: Cambridge University Press.

Sierra, A., \& Frodden, C. (2003). Promoting student autonomy through self-assessment and learning strategies. HOW A Colombian Journal for English Teachers, 10, 133-166.

Strauss, A., \& Corbin, I. (1990). Basics of qualitative research. Grounded theory procedures and techniques. London, UK: Sage Publications.

Torres Díaz, S. P. (2009). Promoting critical thinking through the use of portfolios and self-assessment, HOW A Colombian Journal for Teachers of English, 16, 25-54.

Usma, J., \& Orrego, L. M. (2009). La autonomía del estudiante y del profesor en estudios de investigación acción: Hallazgos y retos desde la Universidad de Antioquia [Student and teacher autonomy in action-research studies: Findings and challenges from
Promoting adolescent EFL students' decision-making through work plans gathered in their portfolios Yudiht Milena Martin Celis, Melba Libia Cárdenas

the Universidad de Antioquia]. In M. L. Cárdenas (Ed.). Investigación en el aula en L1 y L2. Estudios, experiencias y reflexiones [Research in the $\mathrm{L} 1$ and L2 classroom. Studies, experiences and reflections] (pp. 69-87). Bogotá, CO: Centro Editorial Facultad de Ciencias Humanas.

Zembylas, M., \& Lamb, T. E. (2008). Interrogating the notion of autonomy in education: tensions and possibilities. In M. Jiménez Raya, \& T. Lamb (Eds.), Pedagogy for autonomy in language education: Theory, practice and teacher education (pp. 21-35). Dublin, UK: Authentik. 